\title{
Gender and Migrations
}

Written by Nasara Cabrera Abu and Inmaculada Fumero de León

This article considers the importance and evolution of the gender perspective in migratory studies. It also underscores some of the main problems that characterise the migration experience of women, such as job placement and family reunification policies. Finally, a brief overview is provided of the specifics of the Canarian context and of how the press in the Canaries covers migrant women.. 


\section{Introduction: the importance and evolution of the gender perspective in migratory studies}

In the strict sense, the concept of gender refers to a social construct based on sexual differentiation that projects onto the public imagination the meanings attributed to masculinity and femininity. It also implies the relationships and power practices that condition people's life experiences based on their sex, establishing a hierarchy in which the male gender is above the female. In a broad sense, therefore, gender constitutes an axis of social inequality and a principle of social organisation, and thus of migratory experiences and flows. Its introduction into studies on migration occurred as a result of the incipient emergence of gender studies in academia, which resulted from the demands of feminist movements. The gender perspective has not only helped to make the experiences of migrant women more visible; it has also served to underscore how gender systems condition migration and all that this entails. Migrations, in turn, also influence gender relations, in this case they can reproduce or transform them. For all these reasons, the gender perspective in studies on migration has been vitally important to revealing a whole series of dimensions of social reality associated with the migratory phenomenon that were being obscured and simplified.

Although migrant women first began to be addressed by the international academic literature in the 1970s, the image of them that is conveyed is that of passive subjects, tasked exclusively with the reproductive tasks of the domestic/private domain, economically dependent on men, who have left them in the country of origin to reunite with them later in the country of destination. It will not be until the second half of the 1980s, and especially in the 90s, when the gender perspective is consolidated in migratory studies beyond the sex variable as its own analytical category, giving rise to a differentiated field of study. So much so that, at present, there are proposals to change the concept of feminisation of migrations to that of the generation of migrations (Vicente Torrado, 2015), precisely so as to reflect this change in approach: the leap from the quantitative (greater numerical presence of migrant women) to qualitative (different gender experiences).

The first studies on migration from a gender perspective in Spain were not conducted until well into the 90s, and resulted from a series of doctoral theses in the areas of sociology and anthropology (Aubarell, 2000). It is fair to say that it is a field of studies that has been primarily advanced by women (Aubarell, 2000; Gregorio Gil, 2009). The first publications focused on the sociodemographic characterisation of the female foreign population in Spain, and then diversified to study the nationalities with the highest numerical presence - at the time Filipinos, Dominicans, Peruvians, etc. -. Many of these studies rely on a transnational perspective, in which "the gender category is used as a way to make women visible and restore their agency in the construction of transnational life" (Gregorio Gil, 2012, p. 574). One of the results of combining the transnational perspective and the gender variable has been the consequent and necessary politicisation of the sustainability of life (care), that is, the establishment of the inseparable link between family and kinship with economic and political relationships (Gregorio, 2012).

And so, since its inception, publications in the Spanish context brought to light the role of women as precursors of their own migration processes, far from that stereotypical image of reunited migrant women (Oso and Ribas, 2012). Two monographs in the journal Papers provide a good summary of the evolution of these studies. The first, in the year 2000, dealt with 'Female Immigration in Southern Europe'; the second, published in 2012, illustrated the main transformations in female migrations in the first decade of the 21st century and proposed new areas of research that accounted for the wide complexity and diversity of 
the phenomenon. While the former attempted to document the feminisation of migrations and the labour integration of migrant women in certain feminised and devalued sectors, the latter focused on the effects of the global capitalism crisis on the lives of these women and their families. In summary, the focus was shifted from women in the labour market to the transnational family (Oso and Ribas, 2012).

Publications on migration in the context of the Canary Islands have mirrored the growth of migratory flows to these islands. In this field, the gender perspective has held a minority role. In fact, it did not surpass $4 \%$ of all publications on migration until a decade ago (Mesa Marrero and Zapata Hernández, 2008). In this regard, there has been no significant change in recent years. The main contributions have come from the fields of geography, economics and, to a lesser extent, sociology and anthropology. The issues addressed from this gender perspective revolve around the sociodemographic characterisation of migrant women who settled in the Archipelago (Guerra Talavera, 2006); the population of undocumented immigrants (González Rodríguez and Mesa Marrero, 2007) and irregular migratory flows (Domínguez Mujica and Guerra Talavera, 2005); the labour market (Godenau and González Rodríguez, 2008); the analysis of specific national groups, such as Senegalese women (Domínguez Mujica, 2011), and of unaccompanied foreign female minors (Torrado MartínPalomino, 2012); and on the Canarian migration process to Venezuela, specifically, on the different rates of return of Canarian and Creole women, the reproduction of gender roles and their influence on identity dynamics (Ascanio, 1998).

However, studies are scarce, making it necessary to cover both the topics already addressed and the different aspects of the reality of migrant women in the Canary Islands, such as their integration, second generations, women suffering from domestic violence, their participation in civil society, and others. It is important to underscore the need to include qualitative studies that delve into the perspective that women themselves have of their heterogeneous and multiple experiences.

According to Hondagneu-Sotelo (2018), these thirty years of research on gender and migration have yielded six main categories. The first is the dominant approach of the social sciences, whose objective has been to institutionalise gender in migratory studies. A second, later category focuses on the relationship between migration and care work. The third branch has focused on sexualities from the standpoint of humanities, cultural studies and queer studies. The fourth current is the one that investigates and theorises about sex trafficking and human trade. A fifth category stems from post-colonial and decolonial studies, and focuses on identity issues and borders. Finally, a more recent and less developed sixth area addresses the impact of gender and transnational migration on children in the country of origin. However, in all the areas described above, the main topic studied in the field of migration and gender has been the labour market. In addition to these six, another central theme in contemporary research on migration and gender is the study of discrimination and the interaction between different types of oppression systems (gender, race, class, sexual orientation, etc.) from an intersectional approach.

\section{Migrant women and the labour market}

Half of all people currently migrating around the world are women. Female migrations reflect not only economic drivers, but also occur for other reasons, such as patrilocality, when women move into their husband's home; the different distribution of inheritances, which may lead, for example, to abandoning rural areas; or refuge for gender reasons, 
due to persecution or to the impossibility of fulfilling aspirations with traditional gender norms in the place of origin. However, despite the varisous causes of mobility, the search for better living conditions is emerging as the most important among women who move to another country. Similarly, and given the growth of its economy, Spain was ranked as the European country with the highest influx of immigrants in the first decade of the 21 st century. Although in the 1991 census, the number of foreign women in Spain was 180,700 , this population increased, with a total of $2,305,350$ foreign women registered in the Municipal Population Register as of 1 January $2018^{1}$.

The incorporation of women from developed countries into the labour market, in conjunction with another series of factors, most notably the intensification of structural adjustment policies, which have worsened the living conditions of the populations, especially in poor countries, the aging of the population in European countries, and the low coverage in the states of Southern Europe in terms of providing social rights and care services (assistance to dependent persons, nurseries, etc.), have generated a great demand for private domestic services, a demand that has been primarily met by migrant women. In the Spanish case, this sector employs mostly women from Central and South America and, more recently, those from Eastern European countries (Godenau and González Rodríguez, 2008).

In the Spanish labour market, the foreign population is concentrated in the so-called secondary segment (consisting of low-skilled, manual and precarious occupations). Some of the labour niches in this segment are domestic service, agriculture, hospitality, construction and retail. According to data from the Labour Force Survey for the first quarter of 2019, most foreign women worked in two types of occupations: "catering, personal, protection and sales services", and in the "elementary occupations", which include domestic, cleaning and kitchen services, among others².

According to statistical data on Social Security enrolment as of 31 May 2019, of all the foreign women enrolled $(947,187)$, the majority are in the general regime $(61.4 \%)$, followed by $17 \%$ who are registered in the special system of domestic workers, $13.2 \%$ who are self-employed, $8.3 \%$ in the special agricultural regime and $0.1 \%$ in the special sea regime ${ }^{3}$. These figures provide only an approximation, especially in domestic jobs, with a large percentage in the informal economy.

Most of the academic literature notes that foreign women gravitate toward the services sector, with a high concentration in domestic services, followed by cleaning services, hospitality, self-employment and sex work. Given the characteristics of these types of employment (the special regime for domestic workers; job instability; part-time work; irregular or no labour rights and the vulnerability associated with sex work), these women have less access to the social rights related to employment, with all that this entails when combined with their legal status as foreigners. And so we find that the Spanish labour market is not only characterised by ethnostratification (occupations based on the place of origin), but it is also marked by a persistent division of labour along gender lines.

This panorama places migrant women at the bottom rung of Spain's social structure, making them one of the most socially vulnerable groups. There are many problems to be found at the intersection of gender, nationality, and social class. Most notably among them is the greater probability of being in a situation or at risk of social exclusion; the lack

1 Sourcee: www.ine.es

2 According to the 2011 National Classification of Occupations (CNO-2011).

3 Source: www.seg-social.es. 
of support networks in the host society, with the reconciliation problems this entails and, therefore, the increased obstacles to regrouping family members; isolation, which can, in turn, cause a greater likelihood of enduring situations of gender violence; prostitution as a way of subsisting in an irregular administrative status or as the only way at certain times to obtain income (shelter employment); and the inconsistency of status in the case of those women who are overqualified for their jobs.

Family reunification policies, conceived from a masculine standpoint, deserve special mention. Spain's current Immigration Law restricts the reunification of ascendants to persons over 65 years of age, and requires the applicant to have a permanent resident card. This implies two important issues. The first concerns those "grandparents", or rather, "grandmothers" under 65 years of age who, as is also the case in Spain, provide an important support network to help balance the family and work lives of foreign women in the host society This situation limits their reproductive rights (Díaz Gorfinkiel, 2015). Moreover, the specifics of the majority of work situations these women find themselves in are not conducive to conditions suited to obtaining permanent residency status. This creates a vicious circle that hinders their upward social mobility. This phenomenon, called sticky floor, reflects the problems that women in low-skilled jobs face when trying to improve their working and social conditions (Torns and Recio, 2012).

\section{A brief overview of female migrations in the Canary Islands}

The foreign population of the Canary Islands started to boom starting in the second half of the 1980s. This increase stemmed from the islands' appeal as a tourist destination and from Spain's entry into the European Union. The economic growth of the 1990s favoured the development of the tourism, services, commerce, construction and transport sectors, which considerably increased the employed population (Díaz Hernández, Domínguez Mujica and Parreño Castellano, 2001). The economy of the Canary Islands is currently a tertiary economy in which the tourism sector predominates as the driver of the economy. It is also characterised by having an economic structure that relies heavily on the secondary segment of the labour market (low-productivity activities, intensive use of manual labour and low wages) (Godenau and Buraschi, 2017). It is precisely this segment that accounts for a large part of the foreign population working in the Canary Islands.

\begin{tabular}{l|c|c|c|c|c|c|c|c|c|c|c|c|}
\hline & \multicolumn{2}{|c|}{$\begin{array}{c}\text { General } \\
\text { Regimen }\end{array}$} & \multicolumn{2}{c|}{$\begin{array}{c}\text { Special R. } \\
\text { Agriculture }\end{array}$} & $\begin{array}{c}\text { S.R. Domestic } \\
\text { Activity }\end{array}$ & \multicolumn{2}{c|}{$\begin{array}{c}\text { S.R. Self- } \\
\text { Emp. W* }\end{array}$} & \multicolumn{2}{|c|}{$\begin{array}{c}\text { S.R. } \\
\text { Fishery }\end{array}$} & \multicolumn{3}{|c|}{ Total } \\
\hline & M & F & M & F & M & F & M & F & M & F & M & F \\
\hline UE & 16.435 & 18.892 & 368 & 304 & 23 & 190 & 10.204 & 6.561 & 215 & 164 & $\mathbf{2 7 . 2 4 5}$ & $\mathbf{2 6 . 1 1 1}$ \\
\hline Non UE & 19.544 & 13.477 & 1.389 & 181 & 242 & 2.113 & 4.196 & 3.131 & 278 & 11 & $\mathbf{2 5 . 6 4 9}$ & 18.913 \\
\hline Total & $\mathbf{3 5 . 9 7 9}$ & $\mathbf{3 2 . 3 6 9}$ & $\mathbf{1 . 7 5 7}$ & $\mathbf{4 8 5}$ & $\mathbf{2 6 5}$ & $\mathbf{2 . 3 0 3}$ & $\mathbf{1 4 . 4 0 0}$ & $\mathbf{9 . 6 9 2}$ & $\mathbf{4 9 3}$ & $\mathbf{1 7 5}$ & $\mathbf{5 2 . 8 9 4}$ & $\mathbf{4 5 . 0 2 4}$ \\
\hline
\end{tabular}

Table 1

Social security regimes of occupied foreign residents in the Canary Islands.

Source

Social Security, 31 of May 2019.

* Special Regime for Self-Employed Workers

Table 1 shows the number of people enrolled in social security in the Canary Islands by type of regime as of 31 May 2019 by gender and by EU citizenship ${ }^{4}$. Women of EU origin outnumber men from the same place of origin in the general regime and in the regime

4 Data by nationality were used because the social security statistics do not collect data by place of origin. As a result, a significant portion of the population of immigrant origin is omitted. 
of domestic workers. It should be noted that non-professional caregivers are included in the general regime data, which may also include domestic or care services for dependent persons. These women mostly enrol in the general regime and the special regime for selfemployed workers. Women from third countries are enrolled in the general regime, the special regime for self-employed workers and the special regime for domestic workers, the last of these being the only regime in which they considerably outnumber men from the same place of origin, and the only one in which non-European women outnumber European women in total enrolment.

Graphs 1 and 2 show the trend in the population of immigrant origin by sex in Spain and the Canary Islands from 2002 to 2019. In both cases, the female population has grown level with the male population over time, especially since 2013 in Spain and 2014 in the Canary Islands. Although in 2002 the number of men was much higher than that of women (double in the Canary Islands), nowadays women have reached a slight majority both in the Canary Islands and in Spain as a whole. By 2005, migrant women in Spain had doubled their numbers compared to 2002, while in the Canary Islands, the female population doubled in 2008. Until 2014, the migratory balance in the Canary Islands was positive, despite having decreased. It was in 2015 when it turned negative, due primarily to the departure of both non-EU foreigners and Canary Island locals and to the decrease in arrivals (Godenau and Buraschi, 2017).

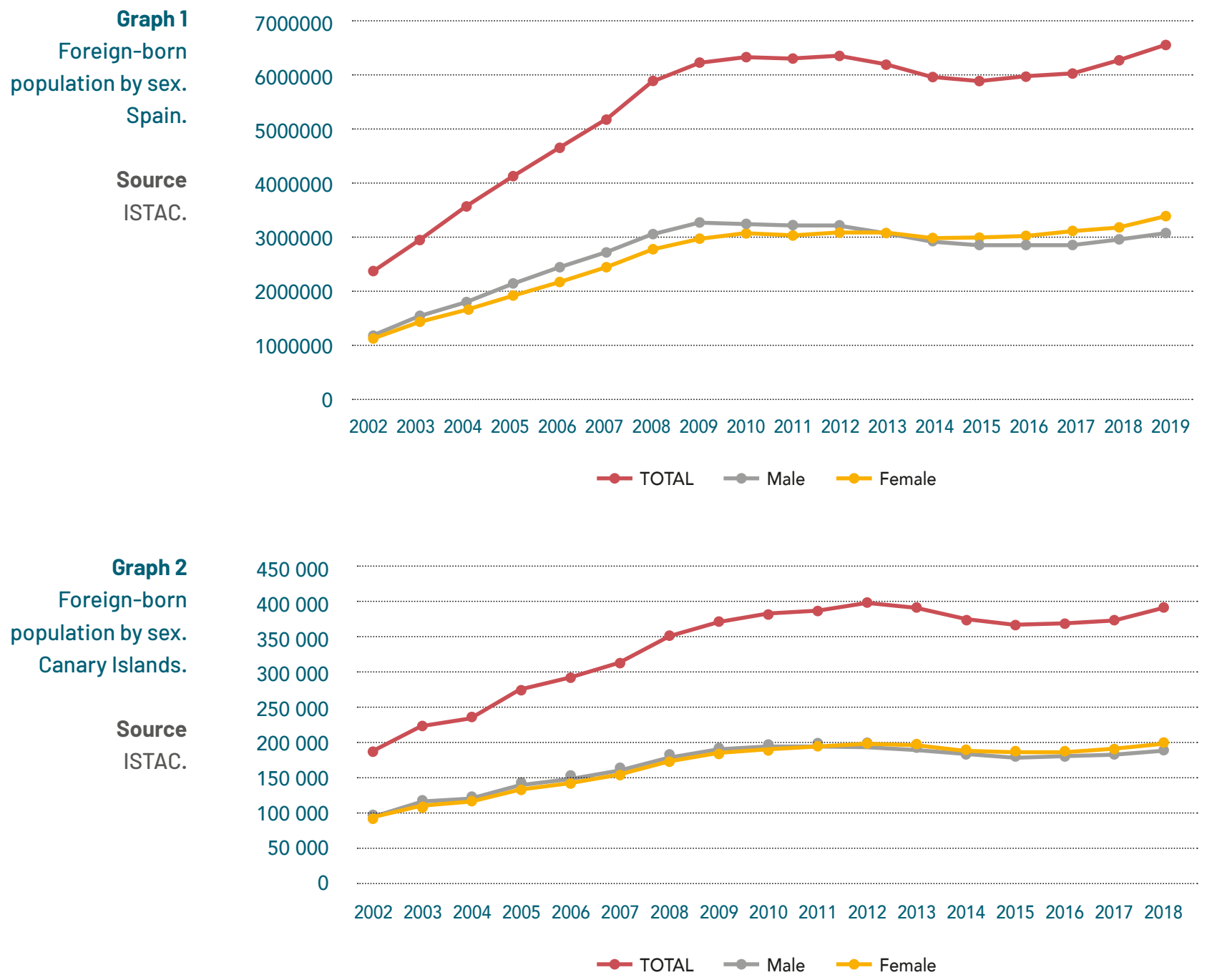


The Canary Islands rank fourth among Spain's regions in terms of its immigrant population, after Catalonia, Madrid and Andalusia. The population of immigrant origin accounted for $18.6 \%$ of the population residing in the Archipelago as of 1 January 2018 . The main sources of this population are: Venezuela (14.8\%), Cuba (9.8\%), Italy (9.3\%), Colombia (7.2\%) Germany (6.6\%), United Kingdom (6.3\%), Morocco (5.9\%), and Argentina (4.3\%) In relation to the predominance of the European population, the percentage of retirees is notable. Except for the Italian group, which contains more men than women, in the remaining groups of European origin, as well as in those from Latin America and Cuba, women outnumber men, slightly in the former and more significantly in these last two groups. However, the female presence is highest in the population of Colombian origin. In this sense, the tendency toward equilibrium in the genders of the various origins has to do with family reunification processes, where the main role is played by women in the case of Latin America, and by men in the case of Morocco.

The foreign population ${ }^{6}$ is clustered in four of the seven Canary Islands. These are as follows: Tenerife (45\%), Gran Canaria (25.5\%), Lanzarote (12.7\%) and Fuerteventura (12.3\%). The majority of this population resides in the capital municipalities, with the exception of Tenerife, where it is mainly concentrated in the municipalities on the island's south. The distribution by sex follows the same pattern as for the whole of the Archipelago. As for the age composition (Graph 3), most women are between the ages of 30 and 39. This is slightly below the age bracket for men, who fall into the 35 to 44 range.

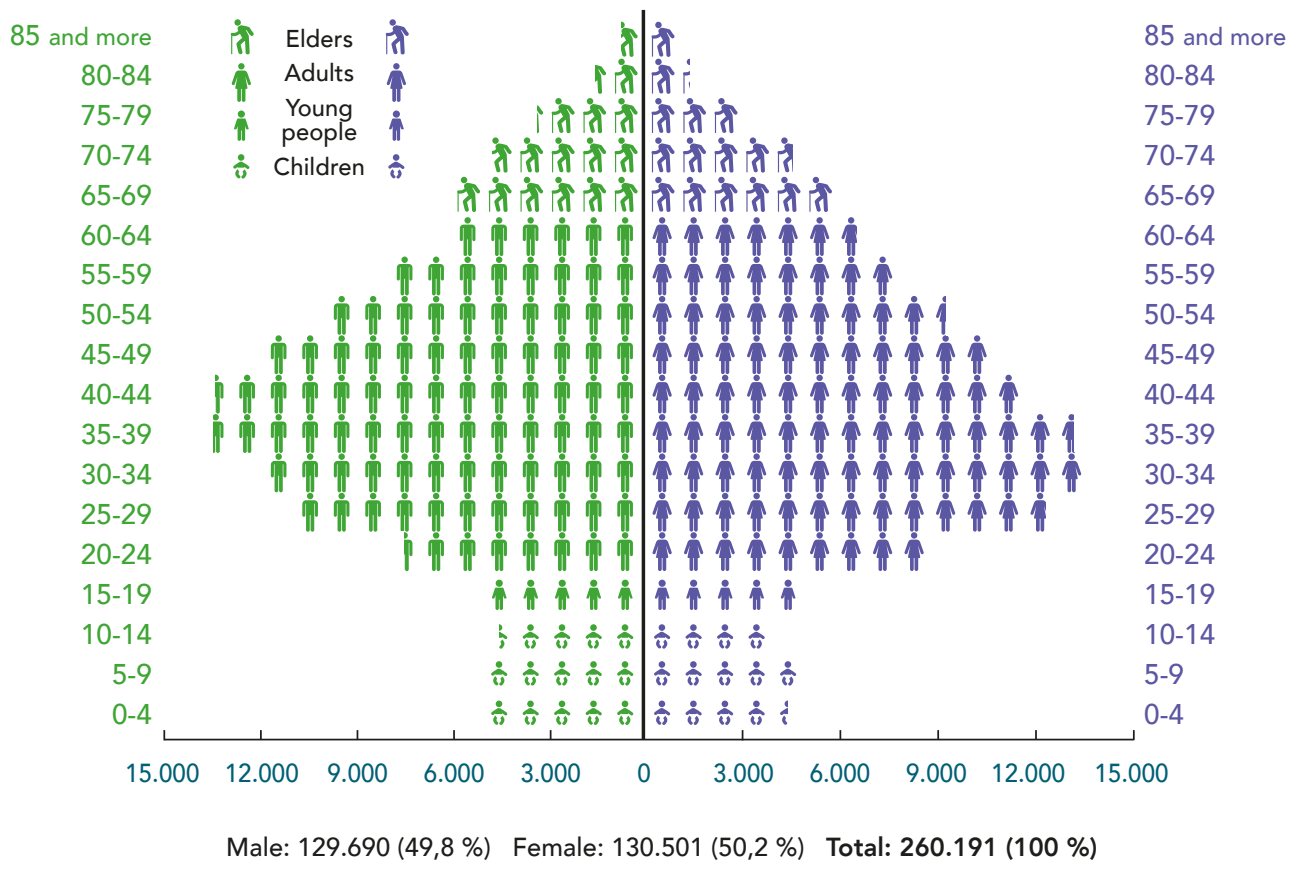

The geopolitical situation of the Canary Islands, as a border region close to the west coast of the African continent, has led to the entry of irregular immigration flows, which peaked in 2006. After that year, the flows decreased until 2017, when they began to increase again. According to the data from the population regularisation process from 2000 and 2001, women who entered through irregular routes accounted for a third of all the people who arrived in the Canary Islands by that route (Domínguez Mujica and Guerra Talavera,

5 The percentages indicate the numbers of these national groups with respect to the total population of immigrant origin residing in the Canary Islands.

6 In this case, the population of non-Spanish nationality has been counted, as there are no data by age, sex and place of birth. This population is 134,842 people less than the total population of immigrant origin. The distribution by island probably does not vary much.
Graph 3

Foreign-born population by sex and age, Canary Islands.

\section{Fuente}

ISTAC. Population Register, on January 1 of 2018. 
2005). As concerns the place of origin, most women arrived from Colombia, while the number of women arriving from the African continent were outnumbered by the men from that same region. However, if we consider the nationalities of the people who were placed in Immigrant Detention Centres (IDC) in the Canary Islands in 2016 and 2017, they were from Morocco, Algeria, Gambia, Guinea and the Ivory Coast ${ }^{7}$.

Starting in 1996, unaccompanied foreign minors (UFM) began arriving from Africa alongside others who were reaching the islands by irregular means. Since that year, the flow of minors to the Canary Islands increased, although, as happened with the flows of adults, it has declined in recent years. This migration must be viewed as the result of restrictive policies that hinder immigration on the one hand, and public protection of the child in the host societies on the other. UFM females who arrive in the Canary Islands, despite being a minority, are more vulnerable when they are exposed, to a greater extent than boys, to situations of labour or sexual exploitation. The profiles have varied in terms of sex, origin and causes of mobility, and in recent decades, girls have tended to come from sub-Saharan countries, mainly Nigeria (Torrado Martín-Palomino, 2012). Once they arrive in the Canary Islands, many of the irregular migrants are held in an IDC ${ }^{8}$. These centres are regulated by Royal Decree 162/2014 of 14 March, which describes the rights of interned foreign persons, as well as many other aspects of the centres' operation and structure. Normally, most detainees are men. In 2016, 19 women were placed in IDCs in the Canary Islands?. However, in Spain many of these centres do not comply with the applicable laws, either in terms of the habitability conditions or the care provided to the detainees. This is especially so in the case of women ${ }^{10}$, and specifically those who are in a particularly vulnerable situation, such as pregnant women.

The Canary Islands may be said to lack public policies intended to promote the social integration of the migrant population and foster intercultural values among the local population. They also lack the preliminary studies and analyses needed to craft these policies. Although there are two immigration plans in the Canary Islands - the 1st Canarian Immigration Plan 2002-2004, and the 2nd Canarian Immigration Plan 2006-2008 - these have not yielded concrete measures in local policies. This fact also stems from the lack of coordination between the various Canarian government agencies. All this results in the need for intersectional measures, in particular to integrate migrant women who, as we have described above, comprise a particularly vulnerable group (language difficulties, higher unemployment, precarious working conditions, etc.).

There are studies and political posturing on this matter in Tenerife, both at the island level and in some municipalities, but not in the rest of the islands. In this regard, a political commitment is needed to foster an interculturality that can solve the challenges derived from the greater cultural diversity in society that results from second and subsequent generations of migrants. Also needed is an educational policy that leads to hosting plans beyond simple language training in schools in the Canary Islands. In a society characterised by a growing cultural heterogeneity, policies should not be subject to the whims of the politicians in office; rather, the public duty of these policies is to accommodate social changes and ensure greater social cohesion in the future. With regard to the media's

7 Data from the 2017 Report Sufrimiento Inútil, by the Jesuit Service for Migrants. Taken from https://sjme.org/ wp-content/uploads/2018/06/Informe-CIE-2017-SJM.pdf

8 Currently, only the IDC of Hoya Fría, in Tenerife, is open in the region of the Canary Islands.

9 According to data from the Jesuit Service for Migrants.

10 Some reports note the lack of female officials or the existence of spaces that are not segregated by gender. See report from Doctors of the World at https://voluntariadomdmcanarias.blogspot.com/ 
coverage of migrant women in the local press, it can be concluded that the image that is conveyed is somewhat reductionist. In this regard, the press provides a polarised image that either hyperaccentuates them (as victims) or obscures them as the protagonist of their migration process ${ }^{11}$. The general result is a portrayal associated with their gender: that of mothers, caregivers and sexual objects ${ }^{12}$. In April 2019, an agreement was signed between the Government of the Canary Islands, the media and the professional associations that work in them in order to improve the coverage given to issues involving gender and equality. It is important that this agreement serve to reflect the diversity of situations experienced by migrant women in the Canary Islands..

\section{In conclusion}

Although the issues related to migration from a gender perspective are more numerous and complex than those reflected in this document, we have endeavoured to provide an outline of the most relevant issues. As we have seen, job placement occupies a central place. This is because women who move increasingly do so for economic reasons as they undertake their own life projects. However, women insert themselves into a local structure of opportunities that is a consequence, and at the same time a cause, of the sexual division of labour that still persists in the world. Despite this, many become the heads of their transnational families and this gives them a power that defies the gender order in their societies of origin. With respect to the institutional framework, the patriarchal vision is reflected in the policies and regulations of the countries of origin and destination, where women continue to be "regarded as vulnerable, dependent subjects who generate a high social cost, which will have an impact on their economic, social and legal status" (Torrado, 2012, p. 69). There are critical voices that are calling for women's perspective to be included in studies on them, since the proliferation of publications on migrant women as sex servants, or workers in the devalued domestic space, yields a stigmatised and homogenising image (Gregorio, 2012). However, the question that is worth considering is that, regardless of the place of origin, domestic services remain a women's issue.

11 The article about the media coverage of immigration in the Canarian press can be found at http://obiten.net/ documentos/56/factsheet

12 The press outlets analysed from 2016 to 2018 were: El Día, Diario de Avisos, La Opinión, Canarias 7, Canarias Ahora and La Provincia. 
Para ampliar la información:

Aguilar-Idáñez, M. J. (2014). Inmigración y género. En Baylos Grau, A., Florencio Thomé, C. \& García Schwarz, R. (coords.). Diccionario internacional de derecho del trabajo y de la seguridad social. Valencia: Tirant lo Blanch, pp. 1147-1156.

Ascanio Sánchez, C. (1998). Reconstruyendo olvidos. El proceso migratorio canario desde la perspectiva de género. III Coloquio de Historia Canario-Americana, pp.12131224.

Aubarell, G. (2000). Una propuesta de recorrido bibliográfico por las migraciones femeninas en España. Papers, 60, pp. 391-413.

Díaz Gorfinkiel, M. (2015). La vida familiar en la inmigración: el caso de las empleadas domésticas inmigrantes en España. Report from the $8^{\text {th }}$ Congress in International Migrations in Spain: Granada, 16-18 September 2015, S14/74.

Díaz Hernández, R., Domínguez Mújica, J. \& Parreño Castellano, J. M. (2001). La inmigración exterior como promotora de cambios sociodemográficos en Canarias. Scripta Nova. Revista Electrónica de Geografía y Ciencias Sociales, 94(12). Taken from http://www.ub.edu/geocrit/sn-94-12.htm

Domínguez Mujica, J. (2011). Migraciones de mujeres y perspectiva de género: senegalesas en Canarias. Revista de derecho migratorio y extranjería, 28, 2011, pp. 101-120.

Domínguez Mujica, J. \& Guerra Talavera, R. (2005). Women and irregular mobility flows in the European Ultraperiphery: the example of the Canary Islands. Belgeo Revue Belge de Géographie. Société Royale Belge de Géographie, 1-2, Leuven: Société Royale Belge de Géographie, pp. 245-258.

Godenau, D. \& Buraschi, D. (2017). Movilidad y condiciones de vida de los inmigrantes durante la crisis económica en Tenerife. Santa Cruz de Tenerife: Área de Empleo, Comercio, Industria y Desarrollo Socioeconómico del Cabildo Insular de Tenerife.

Godenau, D. \& González Rodríguez, R. (2008). Mujer inmigrante y mercado de trabajo. En Bañón Hernández, A. M. (coord.). Comunicación, empleo y mujer inmigrante. Gakoa liburuak, pp. 95-128.

González Rodríguez, R. \& Mesa Marrero, A. (2007). La inmigración irregular desde la perspectiva de género. En Godenau, D. y Zapata Hernández, V. (coords.). La inmigración irregular en Tenerife. Santa Cruz de Tenerife: Área de Desarrollo Económico del Cabildo de Tenerife, pp. 323-346.

Gregorio Gil, C. (2012). Tensiones conceptuales en la relación entre género y migraciones. Reflexiones desde la etnografía y la crítica feminista. Papers, 97(3), pp. 569-590.

Gregorio Gil, C. (2009). Silvia, ¿quizás tenemos que dejar de hablar de género y migraciones? Transitando por el campo de los estudios migratorios. Gazeta de Antropología, 25(1), pp. 1-17. 
Guerra Talavera, R. (2006). La inmigración extranjera desde una perspectiva de género. La mujer inmigrante del siglo XXI en Canarias. Vector Plus, 28, Fundación Universitaria de Las Palmas, pp. 49-60.

Hondagneu-Sotelo, P. (2018). Estudios de género y migración: Una revisión desde la perspectiva del siglo XXI. Autoctonía. Revista de Ciencias Sociales e Historia, 1(2), pp. 26-36.

Mesa Marrero, A. \& Zapata Hernández, V. (2008). Guía Práctica para la investigación de la inmigración en la escala local. Observatorio de la Inmigración de Tenerife. Santa Cruz de Tenerife.

Oso, L. \& Ribas-Mateos, N. (2012). De la sorpresa a la incertidumbre: abriendo etapas en el estudio de la temática sobre género y migración en el contexto español. Papers, 97(3), pp. 511-520.

Torns, T. \& Recio, C. (2012). Desigualdades de género en el mercado de trabajo: entre la continuidad y la transformación. Revista de Economía Crítica, 14, pp. 178-202.

Torrado Martín-Palomino, E. (2012). Las migraciones de menores no acompañados desde una perspectiva de género. llemata, 10, pp. 65-84.

Vicente Torrado, T. L. (2015). Evolución de la incorporación de las mujeres en los estudios migratorios en el contexto español. Report from the $8^{\text {th }}$ Congress in International Migrations in Spain: Granada, 16-18 September 2015, S19/18.

\section{How to cite this article:}

Cabrera Abu, N. \& Fumero de León, I. (2019). Gender and Migrations. OBITen Factsheet 4-2019. Taken from www.obiten.net.

https://doi.org/10.25145/r.obitfact.2019.11

The Tenerife Immigration Observatory is a joint initiative of the Tenerife Council and the University of La Laguna that is intended to provide a permanent and dynamic structure to advance our scientific knowledge of migratory movements. The OBITen carries out its activity by gathering, producing and disseminating knowledge to facilitate qualified opinions and promote the making of decisions that help to better manage migratory phenomena and their implications.

http://www.obiten.net 